\title{
CHIMNEY-GRAFT TECHNIQUE TO TREAT A TYPE IA ENDOLEAK AFTER A PREVIOUS EVAR
}

\author{
EGAN L. KALMYKOV, WAEL AHMAD, PAYMAN MAJD, JAN S. BRUNKWALL
}

Department of Vascular and Endovascular Surgery, University Hospital of Cologne, Cologne, Germany

A 73 year old man who underwent an elective EVAR procedure in 2014 for an infrarenal AAA presented two years later with a type IA endoleak. The CTA showed a distal migration of the proximal part of the stent graft resulting in a type IA endoleak. In order to treat this new diagnosed endoleak an endovascular repair using chimney technique (with a snorkel-stent graft in the renal artery-bilaterally) with proximal extension of sealing zone with an endovascular aortic cuff has been undergone with implantation of a stent graft in the right renal artery as a periscope and a chimney in the left renal artery. Subsequently, an Endurant II Aortic Cuff was implanted. The whole procedure was performed using $\mathrm{CO}_{2}$ instead of iodinated contrast medium. In the 5 month follow-up with abdominal ultrasonography no endoleak could be identified with stabilization of aneurysmal sac diameter. The use of chimney technique adds an additional tool to the armamentarium of endovascular surgeon to deal with the complex type IA endoleaks.

Keywords: Abdominal aneurysm, $\mathrm{CO}_{2}$ angiography, chimney-graft technique, type IA endoleak, periscope technique.

For citation: Kalmykov EL, Ahmad W, Majd P, Brunkwall JS. Chimney-graft technique to treat a type IA endoleak after a previous EVAR. Vestnik Avitsenny [Avicenna Bulletin]. 2019;21(2):347-50. Available from: http://dx.doi.org/10.25005/2074-0581-2019-21-2-347-350.

\section{ИСПОЯЬЗОВАНИЕ ТЕХНИКИ «СНІМNЕҮ» В УСТРАНЕНИИ ЭНДОЯИКА ІА ТИПА ПОС ЯЕ ЭНДОПРОТЕЗИРОВАНИЯ БРЮШНОЙ АОРТЫ ПРИ ЕЁ АНЕВРИЗМЕ}

\author{
Е.А. КАЯМЫКОВ, В. АХМАД, П. МАЖД, Я.З. БРУНКВАЯЬ
}

Клиника сосудистой и эндоваскулярной хирургии, Университетская клиника города Кёльн, Кёльн, Германия

Представлен случай устранения эндолика IA типа у 73 летнего пациента, которому в 2014 году была проведена плановая процедура имплантации эндографта по поводу инфраренальной аневризмы брюшной аорты. По данным компьютерной томографии была установлена дистальная миграция проксимальной части эндографта, что привело к развитию эндолика IA типа. Процедура эндоваскулярного восстановления с использованием chimney technique (snorkel-stent обеих почечных артерий) с проксимальной экстензией зоны фиксации с помощью эндоваскулярной манжеты завершена имплантацией стент-графта в правую почечную артерию реriscope техникой, а в левую - техникой сhіmnеу. Имплантирована аортальная манжета Endurant II. Процедура выполнена с помощью СО 2 контрастирования, вместо йодсодержащего контрастного вещества. Через 5 месяцев, при УзИ брюшной полости, эндолики не выявлены, диаметр аневризмы стабилен. Использование регіsсоре и сhітпеу техник является дополнительным инструментом для борьбы с серьёзными осложнениями, присущими для эндолика типа ІА.

Ключевые слова: аневризма аорты, СО, ангиография, chimnеу техника, periscope техника, IA тип эндолика.

Для цитирования: Kalmykov EL, Ahmad W, Majd P, Brunkwall JS. Chimney-graft technique to treat a type IA endoleak after a previous EVAR. Vestnik Avitsenny [Avicenna Bulletin]. 2019;21(2):347-50. Available from: http://dx.doi.org/10.25005/2074-0581-2019-21-2-347-350.

\section{INTRODUCTION}

The abdominal aortic aneurysm (AAA) is associated with a high risk of rupture and mortality [1]. In the last decade, the endovascular aortic aneurysm repair (EVAR) became the key method of treatment of infrarenal AAA. Despite the advantages of EVAR it raises a number of serious specific complications, of which endoleaks are the most common and may require further endovascular intervention or even open repair in order to prevent a further aneurysm growth and a possible rupture. The real incidence of type I endoleak is not specified but according to the data of The European Multicenter Experience of Endovascular Aortic Aneurysm Repair with the Endurant Stent-graft, the endoleak type I has been detected in $2.2 \%$ of patients in the first year after EVAR procedure [2]. The results of Endurant stent graft System in the US demonstrated a $99.2 \%$ freedom from aneurysmrelated mortality after 4 years of follow-up [3].

Cases of aneurysm related death due to rupture caused by persistent type IA endoleak have been reported [4-6]. Treatment options for the type IA endoleak after EVAR are open conversion surgery and more frequently including endovascular procedures and one of the options is to extend the proximal sealing zone of the implanted stent graft. In the present work, we report the use of chimney-graft technique to treat a type IA endoleak in a AAA-patient treated previously with an EVAR procedure.

\section{CASE REPORT}

A 73 year old man who underwent an elective EVAR procedure in 2014 for an infrarenal AAA presented two years later with a type IA endoleak seen on a computed tomography angiography (CTA) scan with a $3 \mathrm{~mm}$ increased diameter of the aneurysmal sac. The CTA showed a distal migration of the proximal part of the stent graft resulting in a type IA endoleak (Fig 1).

The diameter and length of the aortic neck before the first EVAR were $22 \mathrm{~mm}$ and $24 \mathrm{~mm}$ respectively. The angulations were $\alpha$-angle $=82^{\circ}$ and $\beta$-angle $=25^{\circ}$ respectively. The preoperative comorbidities included arterial hypertension, a history of myocardial infarction, and a history of appendectomy and hernia. The patient had no aneurysm-related symptoms. In order to treat this new diagnosed endoleak we planned to perform an endovascular repair using chimney technique (with a snorkel-stent graft in the renal artery-bilaterally) with proximal extension of sealing zone with an 


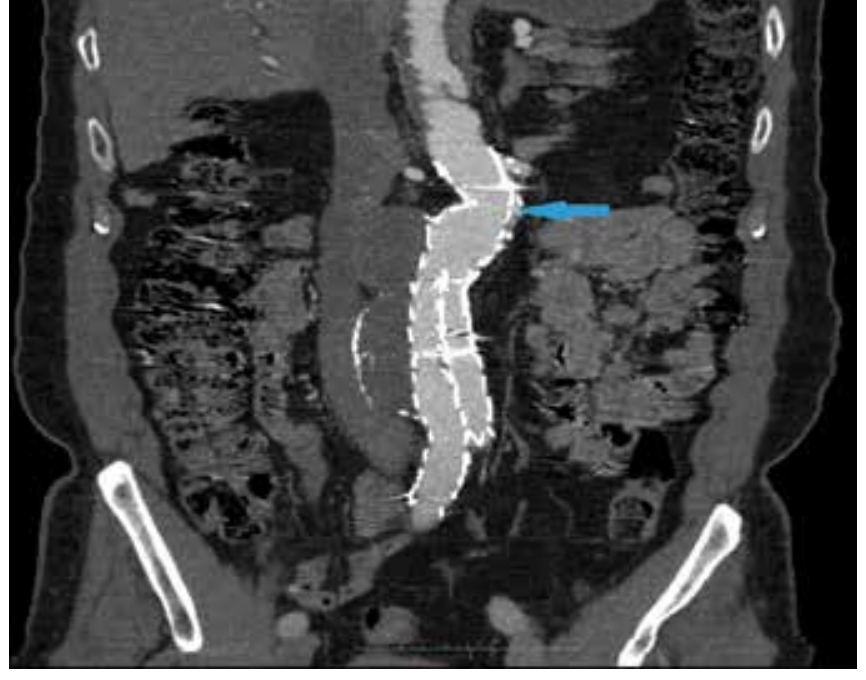

Fig 1 Preoperative CT-Angiography shows the type IA endoleak at the proximal end of endostent (arrow)

endovascular aortic cuff. During the operation, the right renal artery could not be cannulated through the trans-axillary access so that we decided to implant the stent graft in the right renal artery as a periscope (Viabahn $6 \mathrm{~mm} \times 5 \mathrm{~cm}$, W.L. Gore \& Associate, Flagstaff, Arizona, USA) after cannulation through a femoral access and a chimney in the left renal artery trans-axillary (Advanta $6 \mathrm{~mm} \times 38$ $\mathrm{mm}$, Maquet, Rastatt, Germany). Subsequently, an Endurant II Aortic Cuff (proximal and distal cuff diameter were $36 \mathrm{~mm}$ with a length of $49 \mathrm{~mm}$ ) was implanted (Medtronic Inc., Fridley, Minnesota, USA). The whole procedure was performed using $\mathrm{CO}_{2}$ instead of iodinated contrast medium (the preoperative estimated glomerular filtration rate was $60 \mathrm{ml} / \mathrm{min}$ ).

The postoperatively performed CTA showed that the endoleak type IA had disappeared (Fig 2, 3).

No complications in the post-operative period were observed. In the 5 month follow-up with abdominal ultrasonography no endoleak could be identified with stabilization of aneurysmal sac diameter.

\section{Discussion}

In the recent years, EVAR is becoming more popular. Accumulated experience, as well as creation of new generations of stent-grafts led to a significant reduction of the perioperative complications [7]. The most frequent complication of EVAR is the development of endoleaks that in many cases require repeated interventions and sometime even an open conversion [4, 5]. One of the rare complications in the postoperative period after EVAR but which is potentially dangerous in term of aneurysm rupture is the type IA endoleak which is called the Achilles heel of EVAR.

According to the ENGAGE Registry in which 1262 patients with infrarenal AAA treated endovascularly (EVAR) using Endurant stent graft from 79 sites in 30 countries were recruited, endoleaks could be identified in $138(12.0 \%)$ patients at 30 days thereof 17 (1.5\%) were type I and/or type III. Only one patient had both types present [8].

Causes leading to the formation of type IA endoleak include hostile neck, inappropriate pre-procedural planning, material used outside instructions for use, intra-procedural mistakes, severe

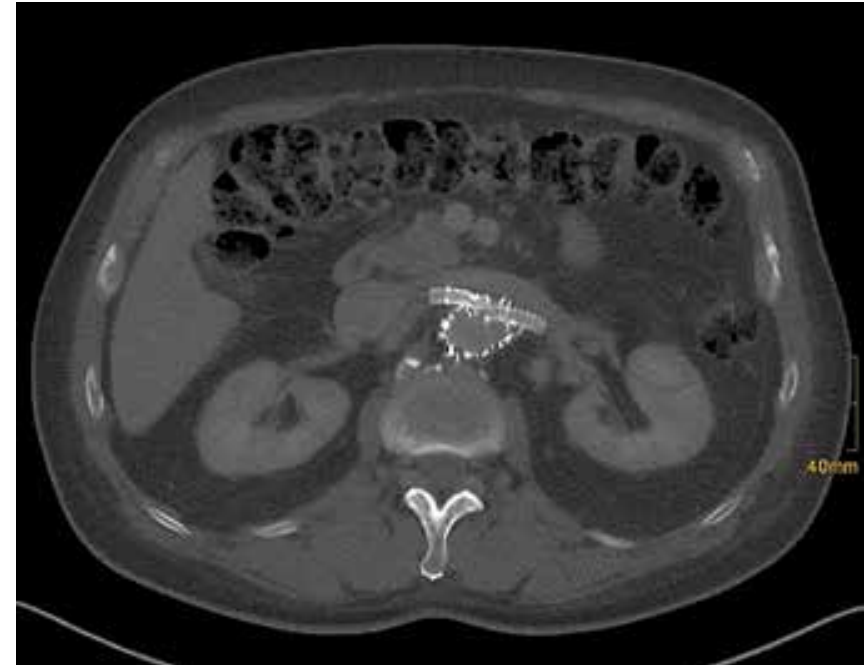

Fig 2 Postoperative CT-Angiography. The renal arteries are perfused through the implanted stent grafts (as chimney on the right side and as periscope at the left). No more endoleak to be seen

angulation of the neck, further progress of the aneurysmal disease and stent migration [9]. In another work, Pecoraro et al [10], compared the results of EVAR procedures using Endurant II stent graft according to the instructions for use versus off-label use in high-risk patients. The authors did not identify any type I endoleaks during a mean follow-up period of $22.61 \pm 12$ months in the off-label group. However, in their systematic review, Antoniou GA et al [11] had demonstrated that type I endoleak was observed in $10 \%$ and $1 \%$ in patients' group treated with EVAR with hostile and normal anatomy respectively after 1 year of follow up. Also, Troisi $N$ et al [12],

Fig 3 3D reconstruction of the postoperative CTA demonstrating the final configuration of the undergone endovascular solution

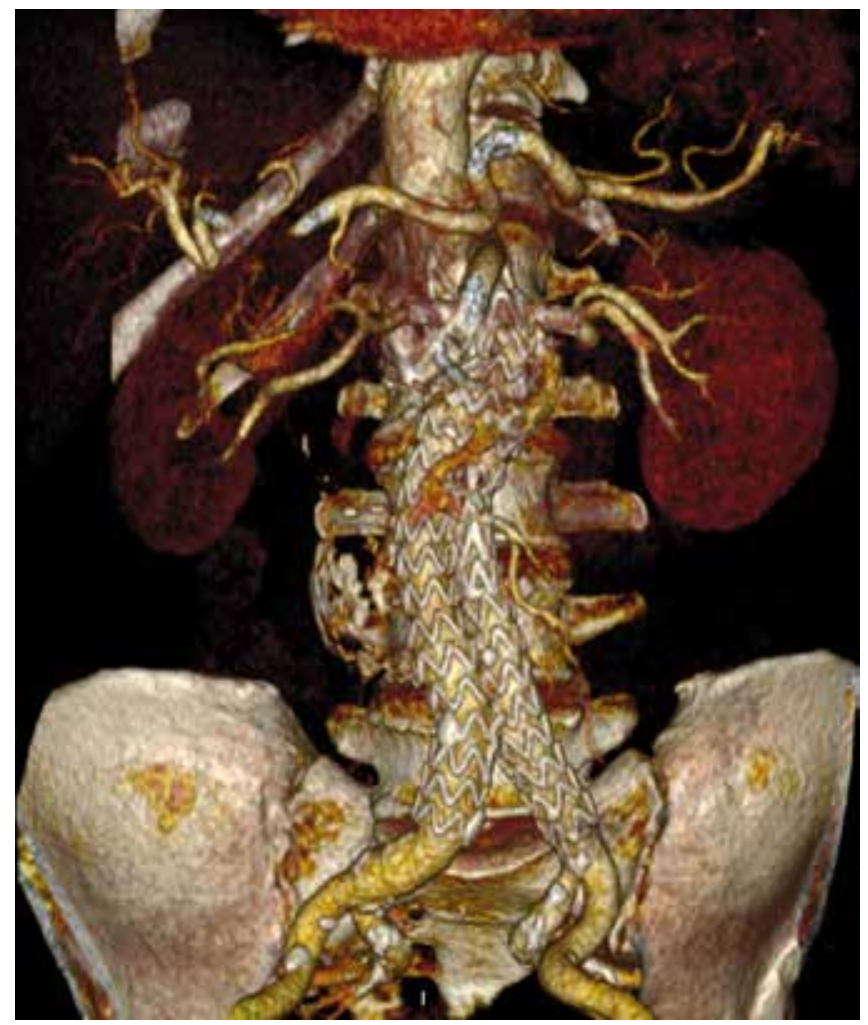


showed in their work, based on an univariate analysis, that proximal aortic neck length $\leq 10 \mathrm{~mm}$, presence of proximal neck thrombus and the chimney technique significantly affect midterm freedom from types $\mathrm{I} / \mathrm{III}$ endoleak (mean follow up period was 9 month). Studying the factors that might augment the risk of developing proximal neck complications after endovascular aneurysm repair using the Endurant stent-graft, Bastos F identified that neck length $<10 \mathrm{~mm}$ and presence of neck thrombus/calcification were independent risk factors for intra-operative neck related adverse events. Also, the female gender, neck length $<10 \mathrm{~mm}$, and AAA maximum diameter $\geq 65 \mathrm{~mm}$ were identified as independent risk factors for postoperative neck related adverse events [13].

Different approaches were applied to treat the endoleak type IA, including endovascular approach and open procedures. Type I endoleaks can be treated with aortic cuff extension, angioplasty at the sealing zone, use of Palmaz stent, use of fenestrated or branched stent grafts, implantation of parallel grafts and embolization using glue or coils [9].

In our case, the patient had two risk factors for developing type IA endoleak: severe neck angulation and the migration of the endoprosthesis as mentioned above. We performed a "neck lengthening" and placement of chimney and periscope grafts in the renal arteries successfully with no relevant postoperative complication. Montelione et al [14], described their experience of treatment of 23 proximal and 1 distal type I endoleak after EVAR using chimney and/or periscope grafts. The reported technical success was $96 \%$; one patient required an additional procedure to seal a recurrent type IA endoleak. Authors identified the estimated survival at 12,24 , and 36 months as $83 \%$; estimated chimney and/ or periscope grafts patency at the same intervals was $94 \%$. Similarly, Donas KP et al [15] reported in their work outcomes of 18 high-risk patients with prior EVAR or chimney-EVAR with type IA endoleak were treated by the chimney technique. Technical success was $94.4 \%$ with no early procedure-related death. Also primary patency of the chimney grafts was $96.7 \%$, and assisted primary patency was $100 \%$. Also chimney procedure can be option for treatment of type IA endoleak after previous chimney EVAR [16].

In conclusion, the type IA endoleak represents a cumbersome problem after EVAR. However, the multiple modalities of treatment options including the endovascular repair, and as we described in our case, the use of chimney technique gives the surgeon additional possibilities to deal with this problem.

\section{REFERENCES}

1. Gawenda M, Brunkwall J. Ruptured abdominal aortic aneurysm: the state of play. Dtsch Arzteb/ Int. 2012;109(43):727-32. Available from: http:// dx.doi.org/10.3238/arztebl.2012.0727.

2. Torsello G, Troisi N, Tessarek J, Torsello GF, Dorigo W, Pulli R, et al. Endovascular aortic aneurysm repair with the Endurant stent-graft: early and 1-year results from a European multicenter experience. J Vasc Interv Radiol. 2010;21(1):73-80. Available from: http://dx.doi.org/10.1016/j. jvir.2009.09.021.

3. Singh MJ, Fairman R, Anain P, Jordan WD, Maldonaldo T, Samson R, et al. Endurant U.S. Pivotal Trial Investigators. Final results of the Endurant Stent Graft System in the United States regulatory trial. J Vasc Surg. 2016;64(1):55-62. Available from: http://dx.doi.org/10.1016/j. jvs.2015.12.048.

4. Kouvelos G, Koutsoumpelis A, Lazaris A, Matsagkas M. Late open conversion after endovascular abdominal aortic aneurysm repair. J Vasc Surg. 2015;61(5):1350-6. Available from: http://dx.doi.org/10.1016/j. jvs.2015.02.019.

5. Калмыков ЕЛ, Садриев ОН. Поздние конверсии после эндопротезирования аневризм брюшной аорты. Ангиология и сосудистая хирургия. 2016;22(3):168-75. Kalmykov EL, Sadriev ON. Pozdnie konversii posle endoprotezirovaniya anevrizm bryushnoy aorty [Late conversions after AAA endografting]. Angiologiya i sosudistaya khirurgiya. 2016;22(3):168-75.

6. Antoniou GA, Georgiadis GS, Antoniou SA, Neequaye S, Brennan $J A$, Torella F, et al. Late rupture of abdominal aortic aneurysm after previous endovascular repair: a systematic review and meta-analysis. J Endovasc Ther. 2015;22(5):734-44. Available from: http://dx.doi. org/10.1177/1526602815601405.

7. Verzini F, Isernia G, De Rango P, Simonte G, Parlani G, Loschi D, et al. Abdominal aortic endografting beyond the trials: a 15-year single-center experience comparing newer to older generation stent-grafts. J Endovasc Ther. 2014;21(3):439-47. Available from: http://dx.doi.org/10.1583/134599MR.

8. Stokmans RA, Teijink JA, Forbes TL, Böckler D, Peeters PJ, Riambau V, et al. Early results from the ENGAGE registry: real-world performance of the Endurant Stent Graft for endovascular AAA repair in 1262 patients. Eur J Vasc Endovasc Surg. 2012;44(4):369-75. Available from: http://dx.doi. org/10.1016/j.ejvs.2012.07.005.

9. Mangialardi N, Orrico M, Ronchey S, Praquin B, Alberti V, Setacci C. Towards an entirely endovascular aortic world: an update of techniques and outcomes for endovascular and open treatment of type I, II, and III endoleaks. J Cardiovasc Surg (Torino). 2016;57(5):698-711.

10. Pecoraro F, Corte G, Dinoto E, Badalamenti G, Bruno S, Bajardi G. Cinical outcomes of Endurant II stent-graft for infrarenal aortic aneurysm repair: comparison of on-label versus off-label use. Diagn Interv Radiol. 2016;22(5):450-4. Available from: http://dx.doi.org/10.5152/ dir.2016.15418.

11. Antoniou GA, Georgiadis GS, Antoniou SA, Kuhan G, Murray D. A metaanalysis of outcomes of endovascular abdominal aortic aneurysm repair in patients with hostile and friendly neck anatomy. J Vasc Surg. 2013;57(2):527-38. Available from: http://dx.doi.org/10.1016/j. jvs.2012.09.050.

12. Troisi N, Torsello G, Donas KP, Austermann M. Endurant stent-graft: a 2-year, single-center experience with a new commercially available device for the treatment of abdominal aortic aneurysms. J Endovasc Ther. 2010;17(3):439-48. Available from: http://dx.doi.org/10.1583/10-3090.1.

13. Bastos Goncalves F, Hoeks SE, Teijink JA, Moll FL, Castro JA, Stolker RJ, et al. Risk factors for proximal neck complications after endovascular aneurysm repair using the Endurant stentgraft. Eur J Vasc Endovasc Surg. 2015;49(2):156-62. Available from: http://dx.doi.org/10.1016/j. ejvs.2014.10.003.

14. Montelione N, Pecoraro F, Puippe G, Chaykovska L, Rancic Z, Pfammatter $\mathrm{T}$, et al. A 12-year experience with chimney and periscope grafts for treatment of type I endoleaks. J Endovasc Ther. 2015;22(4):568-74. Available from: http://dx.doi.org/10.1177/1526602815586972.

15. Donas KP, Telve D, Torsello G, Pitoulias G, Schwindt A, Austermann M. Use of parallel grafts to save failed prior endovascular aortic aneurysm repair and type IA endoleaks. J Vasc Surg. 2015;62(3):578-84. Available from: http://dx.doi.org/10.1016/j.jvs.2015.04.395.

16. Mylonas SN, Moulakakis KG, Kakisis JD, Brountzos EN, Liapis CD. New chimney after chimney EVAR for the treatment of type IA endoleak. Int J Angiol. 2016;25(5):e126-e130. Available from: http://dx.doi. org/10.1055/s-0035-1556055. 


\section{(1) Author information}

Egan L. Kalmykov, MD, PhD, Department of Vascular and Endovascular Surgery, University Hospital of Cologne ORCID ID: 0000-0001-6784-2243

Wael Ahmad, MD, Department of Vascular and Endovascular Surgery, University Hospital of Cologne

ORCID ID: 0000-0001-5090-3468

Payman Majd, MD, Department of Vascular and Endovascular Surgery, University Hospital of Cologne

ORCID ID: 0000-0002-1093-8962

Jan S. Brunkwall, Professor, MD, PhD, Department of Vascular and Endovascular Surgery, University Hospital of Cologne ORCID ID: 0000-0003-3082-6009

Information about the source of support in the form of grants, equipment, and drugs

The authors did not receive financial support from manufacturers of medicines and medical equipment.

Conflicts of interest: The authors have no conflicts of interest.

\section{ADDRESS FOR CORRESPONDENCE:}

Egan L. Kalmykov

MD, PhD, Department of Vascular and Endovascular Surgery, University Hospital of Cologne

50937, Germany, Cologne, Kerpener str., 62

Tel.: +49 (1766) 1533534

E-mail: egan0428@mail.ru

\section{AUTHOR CONTRIBUTIONS}

Conception and design: KEL, BJS

Data collection: KEL, WA, MP

Analysis and interpretation: BJS

Writing the article: KEL, WA, MP

Critical revision of the article: BJS

Overall responsibility: BJS

Submitted $\quad 22.02 .2019$

Accepted $\quad 26.06 .2019$

\section{(i) СвЕДЕНИЯ ОБ АВТОРАХ}

Калмыков Еган Леонидович, кандидат медицинских наук, научный сотрудник клиники сосудистой и эндоваскулярной хирургии, Университетская клиника города Кёльн

ORCID ID: 0000-0001-6784-2243

Ваель Ахмад, врач, научный сотрудник клиники сосудистой и эндоваскулярной хирургии, Университетская клиника города Кёльн ORCID ID: 0000-0001-5090-3468

Мажд Пейман, врач, научный сотрудник клиники сосудистой и эндоваскулярной хирургии, Университетская клиника города Кёльн ORCID ID: 0000-0002-1093-8962

Брункваль Ян Зигге, доктор медицинских наук, профессор, директор сосудистой и эндоваскулярной хирургии, Университетская клиника города Кёльн

ORCID ID: 0000-0003-3082-6009

Информация об источнике поддержки в виде грантов, оборудования, лекарственных препаратов

Финансовой поддержки со стороны компаний-производителей лекарственных препаратов и медицинского оборудования авторы не получали.

Конфликт интересов: отсутствует.

\section{АДРЕС ДЛЯ КОРРЕСПОНДЕНЦИИ:}

Egan L. Kalmykov

MD, PhD, Department of Vascular and Endovascular Surgery, University Hospital of Cologne

50937, Germany, Cologne, Kerpener str., 62

Tel.: +49 (1766) 1533534

E-mail: egan0428@mail.ru

\section{ВКЛАД АВТОРОВ}

Разработка концепции и дизайна исследования: КЕЛ, БЯЗ

Сбор материала: КЕЛ, АВ, МП

Анализ полученных данных: БЯз

Подготовка текста: КЕЛ, АВ, МП

Редактирование: БЯЗ

Общая ответственность: БЯЗ

$\begin{array}{ll}\text { Поступила } & 22.02 .2019 \\ \text { Принята в печать } & 26.06 .2019\end{array}$

